\title{
Dealing with Blasphemy Laws in Indonesia
}

\author{
Heru Susetyo ${ }^{1}$, Abdurakhman $^{2}$, Farida Prihatini ${ }^{3}$, Nurindah Hilimi ${ }^{4}$, Intan Mahabah Nabila ${ }^{5}$, \\ Ira Apriyanti ${ }^{6}$, Suri Rahmadhani ${ }^{7}$ \\ \{ hsusetyo@ui.ac.id $^{1}$ \} \\ Faculty of Law Department of Law and Society, Universitas Indonesia, Indonesia ${ }^{1,3}$ \\ Faculty of Humanities Department of History, Universitas Indonesia, Indonesia ${ }^{2}$ \\ Alumni of Faculty of Law Department of Criminal Law, Universitas Indonesia, Indonesia ${ }^{4}$ \\ Alumni of Faculty of Law Department of Administrative Law, Universitas Indonesia, Indonesia ${ }^{5,6,7}$
}

\begin{abstract}
The rights of religion and belief must be protected, which is a matter of concern for law enforcers in Indonesia. Law enforcers have attempted various case restrictions related to blasphemy, such as the provision of Article 156 (a) of the 1965 Blasphemy Law. Other legal provisions related to blasphemy regulation are regulated on Article 28 paragraph (2) of the Indonesian Law No. 11/ 2008 about Information and Electronic Transaction. Although in the Human Rights Act 1999 and Law No. 12 of 2005 concerning the ratification of the ICCPR, which has also guaranteed freedom of expression and restrictions on religious criticism, it has not been deemed appropriate to resolve various blasphemy issues that occur in Indonesia. In upholding human rights development in blasphemy, the National Commission on Human Rights has also made efforts by establishing a Standard of Norms and Regulations on Freedom of Religion and Belief. Therefore, this research paper will discuss applying the blasphemy law enforced by the Indonesian state with other countries. Besides, seeing the extent to which law enforcement is seen from the universal application of human rights enforced in Indonesia and whether or not the articles in the Blasphemy Law in Indonesia are properly resolved in resolving various blasphemy issues in Indonesia.
\end{abstract}

Keywords: Blasphemy law, Religion, Effectiveness of law enforcement

\section{Introduction}

Based on several media sources in Indonesia, it is found that many cases of blasphemy or blasphemy have been brought before the courts in Indonesia. In the past quartercentury, the Indonesian judiciary has sent many people to prison on the grounds of blasphemy laws [1]. Amnesty International recorded at least 106 on this basis between 2005 and 2014 [2]. The first case example is Tajul Muluk, a Shia leader from East Java, who served four years in prison for blasphemy under Article 156 (a) of the Criminal Code. Tajul Muluk founded a religious boarding school in Nangkrenang, Sampang, Madura Island, East Java, in 2004 and is a school principal. In 2006, the village's Sunni Muslim leaders and religious authorities started their Shi'a teachings as' deviant.' There were many threats and acts of intimidation against him and other Shia followers in the village. On 29 December 2011, Tajul Muluk had to leave his village after about 500 people attacked him and his Shi'a followers. After that, Tajul Muluk and about 20 other villagers, including his family, were prevented from returning to the village by the attackers, who threatened to kill them if they returned. In the end, on January 1, 2012, a fatwa 
was issued by the Sampang branch of the Indonesian Ulema Council (MUI) on what Tajul Muluk called heretical teachings. On March 16, the East Java regional police charged Tajul Muluk with blasphemy based on Article 156 (a) of the Criminal Code. On 12 July 2012, Tajul Muluk was sentenced to two years in prison for blasphemy by the Sampang District Court. In particular, the court found him guilty of saying the Koran used by Muslims was not the original text. Tajul Muluk denied this accusation. He appealed the decision to a higher court. However, his sentence was actually increased to four years on 10 September 2012 by the Surabaya High Court intended to have a "deterrent effect" and because Tajul Muluk had caused "disharmony among Muslims" [3].

Another example is Andreas Guntur, the local leader of Amanat Keagungan Ilahi (AKI), a religious sect in the province of Central Java. He was sentenced to four years in prison for blasphemy in March 2012. In spreading its teachings, the AKI organization is seen as using divine inspiration received by its founders, who reject conventional Islamic rituals. Since 1982 the Serang District Prosecutor's Office has issued a ban on all AKI activities in West Java province. Then, in 2009, the Indonesian Ulema Council (MUI) issued a fatwa against AKI for its "misinterpretation of Islam." Until October 2011, Andreas Guntur held a meeting with his followers in the village of Girimulyo in Klaten Regency, Central Java, when the authorities attacked. They accused him and AKI of practicing deviant teachings, pointing to a series of posters in his house with religious words in Arabic that are not from the Koran. According to Andreas Guntur, the posters were for personal use and had been given to him. by an AKI spiritual leader in Jakarta who used the words on a poster to cure his illness. Since then, he has been interested in these teachings and wants to help heal others through prayer. Andreas Guntur was later arrested and charged with Article 156 (a) Indonesian Criminal Code for blasphemy. He was sentenced to four years in prison in March 2012 by Klaten District Court based on Article 156 (a) of the Criminal Code. The Central Java High Court subsequently upheld this decision in April 2012 and the Supreme Court in August 2012 [4].

Alexander An (Aan), a 30-year-old Civil Servant (PNS) from Pulau Punjung District in West Sumatra province, was jailed for blasphemy in June 2012. Aan was accused of being an atheist for posting statements and pictures on his personal Facebook site and on the "atheist Facebook Group Minang", which some people interpret as insulting Islam and the Prophet Muhammad. According to his lawyer, his posts on Facebook have been printed and distributed by his colleagues. On January 18, 2012, an angry crowd, who had heard of his alleged Facebook post, gathered at his workplace and threatened to beat him. On January 20, 2012, he was accused of "spreading information aimed at inciting religious hatred or enmity" under Article 28 (2) of the Information and Electronic Transactions (ITE) Law. Then he was accused of committing religious blasphemy under Article 156 (a) of the Criminal Code and calling for other people to embrace atheism under Article 156 (b) of the Criminal Code [5].

In Bali, there was a Donald (Donald Ignatius Soeyanto Baria) video case in 2017 [6]. As an example of a case related to blasphemy that reached the Denpasar District Court. It is known that the defendant was legally and convincingly proven to have violated Article 28 paragraph 2 in conjunction with Article 45A of Law Number 11 of 2008 concerning Electronic Information and Transactions (ITE) on a video uploaded on his YouTube channel containing hate speech that smelled of SARA. In particular, Donald, who claimed to be an atheist, insulted Islam and the kyai, because he was dissatisfied with what the scholars said. His actions have caused unrest in the community and triggered the social conflict [7]. However, it can be said that tolerance among religious communities in Bali is quite high. Especially for the native Balinese Hindutraditional people who are the majority. One of them can be seen by the formation of Puja Mandala, a complex containing houses of worship from 5 (five) religions recognized in 
Indonesia. Besides, during the Nyepi celebration, for example, which is a Hindu religious holiday. Communities of other religions such as Islam, Christianity, with high tolerance, "celebrate" through blackout of lights and electricity in every house like the indigenous Hindus in Bali. There is no longer a problem with the consequences of the Nyepi celebration procedure, which can hinder the work and activities of non-Hindus.

Another monumental case is the case of Syiah and Ahmadiyah in East Java. The issuance of a Joint Decree of 3 (Three) Ministers regarding the Indonesian Ahmadiyah Community (JAI), which was issued on 9 June 2008, impacted the existence of the Ahmadiyya Jama'at [8]. In essence, the decree contains the termination, dissemination, interpretation, and activities that deviate from the principles of Islamic teachings, namely the dissemination of understanding that recognizes a prophet's existence with all his teachings after the Prophet Muhammad. The enactment of the Three Ministers Decree has many implications for the right to freedom of religion, ranging from limiting worship activities, not extending land use permits to destroying mosques, where Ahmadiyah congregations' worship [9].

Among the other cases that reached the court was the case of the Shiites in Sampang in Madura. In fact, this case occurred because of property, throne, and women in which two brothers belonged to different genres, namely, Syi'ah and Sunni (Rois and Tajul Muluk). The two men initially fought over a woman who would become a potential wife. This criminal case later developed into a case with the authority of SARA [10]. So, in essence, the Syi'ah Sampang case was motivated by a factor of personal problems, not purely due to religious matters [11].

There is also a case related to the issue of religious blasphemy committed by the Indonesian Student Service Institute (LPMI) from outside Batu City, which occurred at the Asida Hotel at the end of 2006 and was highlighted by the national media and sparked anger at the time Muslim community in the end, the issue of religious blasphemy was brought to court, in the pre-trial trial a Christian leader and FKUB representative (Pdt. Yonathan Maluw) as an expert witness. The presence of Mr. Yonathan and Gus Sirad (Islamic leaders-FKUB) and the mayor at that time (late Imam Kabul) were simultaneously mediators to reduce the anger of the masses and maintain a conducive situation until the problem was resolved in court. Cases of blasphemy or blasphemy in Indonesia are challenges for law enforcement and human rights enforcement in Indonesia. The second amendment to the 1945 Constitution, which came into effect in 2000, guarantees freedom of expression, thought, conscience, and religion. These rights are also protected in Law no. 39/1999 on Human Rights. Furthermore, freedom of thought, conscience, and religion is recognized as underogable rights under Article 28I (1) of the 1945 Constitution and Article 4 of Law No. 39/1999.

Therefore, in the discussion of this article, we wish to explore the dynamics of the implementation of the blasphemy law in Indonesia amidst the country's commitment to the international human rights regime, in particular freedom of expression, thought, conscience and religion, and whether human rights can be applied relatively following the specific conditions of each country. To support this research's purposes, a comparison of the blasphemy laws in Indonesia with several other Southeast Asian countries, such as Malaysia, the Philippines, and Thailand.

\section{Methods}

Data collection for this research was carried out through literature studies and field research in several provinces in Indonesia. In the field research, interviews and observations were 
conducted with different government agencies, community organizations and religious figures. Field research was also carried out abroad, including in Malaysia, the Philippines and Thailand with the aim of getting a good comparison of policies governing blasphemy in neighboring countries.

\section{Results and Discussion}

\subsection{Indonesian blasphemy law}

Article 156a of the Indonesian Criminal Code (Indonesian Criminal Code or KUHP) stipulates that a person can be subject to imprisonment of up to five years if he "deliberately publicly expresses feelings or commits an act: a) which is basically hostile towards, abuses or tarnishes religion which is obeyed in Indonesia; or b) to prevent someone from embracing any religion based on the belief of God Almighty." This article states that without warning, a person who is proven to have committed religious blasphemy will be charged with a maximum penalty of 5 years in prison [12].

Apart from these provisions, the President of Indonesia also issued a decree in 1965 , namely Law no. 1 / PNPS / 1965 concerning the Prevention of Misuse and/or Blasphemy of Religion, which prohibits people from deliberately communicating in public, or advocating or seeking support for, interpretations of religion practiced in Indonesia, or carrying out religiousbased activities that resemble religious activities concerned, where these interpretations and activities deviate from the basic teachings of religion. It was also determined that the six recognized religions in Indonesia are Islam, Buddhism, Protestantism, Catholicism, Hinduism, and Confucianism [13].

According to Andi Hamzah, in the provisions of the elements of Law no. 1 PNPS 1965, seen from the intention of the legislators, this should be an alternative, not a cumulative. This means that only one of them is proven to be convicted of the maker [14]. In this case, what is protected here is freedom of religion and religion's practice without interference from others. Some scholar figures argue that Article 156a of the Criminal Code in letters a and b is cumulative regarding this issue. If one of the letters is not fulfilled, Article 156a cannot be imposed. This article can be seen, that the provision of sanctions in Indonesian legislation for acts of blasphemy of religion Law no. 1 PNPS 1965 with 2 stages, namely giving advice, stern warning (personal) or disbanding (organization/sect), and if he still commits the act then a maximum of 5 years imprisonment [15].

The first objective element of a criminal act regulated in Article 156a of the Criminal Code is the public. Using words in public means that the feelings issued by the perpetrator or the actions carried out by the perpetrator must always occur in public places. Still, it is sufficient if the public can hear the perpetrator's feelings, or the public can see the actions committed by the perpetrator. The perpetrator can issue hostile feelings, abuse, or defamation of a religion adhered to in Indonesia in a public place, which can be visited by anyone, which can be heard by the public, committed by the perpetrator, either verbally or by action [16]. Other objective elements of the criminal acts regulated in Article 156a letter a of the Criminal Code are hostile, abuse, or defamation of a religion adhered to in Indonesia. Regarding which feelings or actions can be viewed as hostile feelings or actions, abuse or defamation of a religion practiced in Indonesia, Law no. 1 PNPS of 1965 did not provide a specific explanation. It seemed like leaving it to the judge in giving the judge's interpretation freely regarding which feelings or actions could be 
seen as hostile, abuse, or defamation of religion in Indonesia [17]. Article 28 paragraph (2) of Indonesian Law No. 11/2008 and Information and Electronic Transactions states the following (under the section 'Prohibited Actions'): Anyone who knowingly and without authority disseminates information that aims to cause hatred or conflict with individuals and/or certain groups of people based on ethnic groups, religions, race, and between groups (usually referred to in Indonesian as SARA). The criminal penalty for the offense is stated in article 45 (2) of the action as follows: (2) Any person who fulfills the elements as referred to in Article 28 paragraph (1) or paragraph (2) shall be subject to imprisonment, not exceeding 6 (six) years and/or a fine not exceeding IDR 1,000,000,000 (one billion rupiahs).

\subsection{Comparative studies with three southeast asian countries}

\subsubsection{Thailand [18]}

The issue of blasphemy law is not specifically regulated in Thai law. Basically, the Thai constitution protects the freedom of its people to practice religions and beliefs they believe. However, there is no specific law regulating the prohibition of blasphemy as in Indonesia. In code 206- 208, the Thai Criminal Code regulates sanctions against blasphemy (especially all religions recognized by the government). The punishment can be sentenced to 1-7 years in prison or a fine ranging from 2000 baht- 14 thousand baht.

Buddhism, which is followed by the majority of Thai people, is protected by law from all forms of religious blasphemy. This cannot be separated from the religion of "Buddha" as one of the state's symbols besides the Monarchy and the Nation/state. It can be seen from the Sangha Act's existence, which specifically prohibits the defamation of Buddhism. Against the law violators, will be subject to a maximum prison term of 1 year or a maximum fine of 20 thousand baht.

There are actually several conflicts in the case of blasphemy. Still, most of them are not purely blasphemy conflicts or do not go to legal channels as is the case that is widely discussed in newspapers, regarding the abuse of Buddhism by a Thai citizen who painted a Buddha statue in colors for artistic reasons (although in fact it can be categorized as an act of blasphemy which can be subject to articles in the related Criminal Code, this case did not go to court). Or the case in Chiang Mai related to the construction of mosques that were opposed by the people around the Laos and Cambodia borders (who are predominantly Buddhist) because there were not many mosque worshipers as required, it was known that the reason for the ban was due to the interests of certain individuals/parties who felt they would be harmed with the construction of mosques in the area.

Currently, the conflict case in Southern Thailand (originating from the population's anger over the disappearance of their group leader) is still negotiating between the government and groups with different ideologies since 2013. On the other hand, the fact is that the government continues to arrest people, especially in Southern Thailand, which is indicated as ethnonationalism (trying to liberate Southern Thailand from the monarchy/kingdom of Thailand). In essence, the strength of the monarchy/kingdom in Thailand affects the existing cases. It is rare for someone to entrap someone based on blasphemy laws, where the government often immediately acts first to try to negotiate with the perpetrators so that they do not get into legal channels. Even to maintain its strength, the government seems to be trying to embrace all religions. Among them, the king and his family must study all religions (apart from Buddhism as the religion they profess). Then for the construction of a religious house itself, there are government subsidies for all religions. 


\subsubsection{Philippines [19]}

When it comes to blasphemy, the Philippines is no ordinary country in this respect. This is because cases of blasphemy in the Philippines are still small compared to other countries. This is due to the cultural spectrum in this country that has mutual respect between religious communities. For Catholics, who make up the majority in the Philippines, Muslims and Christians are brothers. They also respect each other's identities and do not interfere with each other. The government also supports the worship activities of followers of religions in the Philippines, such as building houses of worship, not prohibiting religious activities, and supporting every activity carried out by each religion in the Philippines.

Based on information from a community at the Quiapo Islamic Center, Manila, the government has never discriminated against Muslims. However, in considering socio-political and religious issues, the government does not pay attention to their voices, such as in the case of the bombing in Marawi. At that time, the Philippine Muslims asked not to carry out bombings in areas suspected of being ISIS territory. They asked to send military forces to repel the terrorist herd. In fact, the government continued to carry out bombings and heeded their input. As a result, many of their homes were destroyed by the bombings. However, after the bombing, the government-assisted in rebuilding their homes, but the funds provided were not sufficient to build houses as before.

Although few cases have occurred, there have been cases in this country by an activist named Carlos Celdran. Unfortunately, he died while still in legal proceedings due to health problems. Celdran was subjected to Article 133 of the Revised Penal Code of the Philippines for his shouting in front of Catholics who were performing mass on September 30, 2010, in Intramuros, one of the most historical places in the Philippines, by saying, Damaso, the name of a greedy monk in the novel written by Jose Rizal in 1887. There are many allegations that the blasphemy cases that occurred were not purely to hurt people of other religions but also for political reasons. As happened to Muslims in the southern Philippines.

In its application, the Philippines' Penal Code leaves it to Palos, the Criminal Justice System, which is in the country. The Criminal Justice System is an institution responsible for preventing crime, enforcing the rules, and executing those who break the law. The Revised Penal Code in the Philippines came into effect in January 1932. The article containing the prohibition of defaming other religions is still general and has not specifically regulated acts of blasphemy against other religions. Therefore, the Philippines' blasphemy law should be implemented to protect every religious community and create a sense of mutual respect. Today and in the future, the problem is increasingly challenging.

Another reason behind the absence of regulations regarding this matter is the inconsistency with international conventions regulating a person's civil and political rights. Even though the Philippines has ratified the ICCPR (International Covenant on Civil and Political Rights), it aims to protect the state and the morals of Filipino citizens. That is why the Philippines does not have a law governing the prohibition of blasphemy against other religions. However, in the case of crimes against religion, it is regulated in the Revised Penal Code of the Philippines Book Two (Crimes Against the Fundamental Laws of the State), Chapter One, Section 4 Crimes Against Religious Worship) verses 132 and 133. of the two verses as follows:

- Art. 132. Interruption of religious worship.

The prison correctional penalty in its minimum period shall be imposed upon any public officer or employee who shall prevent or disturb any religion's ceremonies or manifestations. 
If the crime has been committed with violence or threats, the penalty shall be prison correctional in its medium and maximum periods.

\section{- Art. 133. Offending religious feelings.}

The penalty of arrest major in its maximum period to prison correctional in its minimum period shall be imposed upon anyone who, in a place devoted to religious worship or during the celebration of any religious ceremony, shall perform acts notoriously offensive to the feelings of the faithful.

However, the ban does not apply to the President of the Philippines. The president has the right to immunity, which gives him freedom of opinion even if it offends other religions. When Duterte said, "Who is this stupid God? This insolent, utter fool "in a speech held openly and broadcast on Philippine national television in June 2018, in his blatant statement to Catholic religious leaders in the Philippines, Catholics do not need to go to the Church to give money to idiots (read: priests and priests) in the Church in November 2018. Also, he mentioned that Catholic religious leaders are useless and deserving of being killed. Many things were raised by Duterte that cornered one of its religions and leaders in the Philippines. Still, in his capacity as President, the supreme leader of Filipino citizens, he was released from the penalties in Article 132 and Article 133 of the Revised Penal Code.

\subsubsection{Malaysia [20]}

The law against committing blasphemy in Malaysia is divided into two faults. The first is the mistake of insulting or being looked down upon by Islam. The second is to study the holy verses of the Koran and Hadith. The error of insulting religion in the Malaysian communion territory is regulated in Section 7 of the 1997 Fellowship Area Sharia Clearance Deed. This can be seen more comprehensively in Deed 557 Section 7 as follows:

Akta 559 Deed of Error Jenayah Sharia (Communion Areas) 1997 Part III - Errors Related to the Sanctity of Islam and its Institutions

- Seksyen 7. Insulting, or causing to be despised, etc. Islam.

Everywhere, people verbally or in writing or with a visible description or in any other way:

a. insulting Islam or causing Islam to be despised;

b. slaughtering, proclaiming, or defiling practices or ceremonies related to Islam; or

c. hinder or cause contempt in any law currently in power in the Union Territory relating to Islam.

The above rules generally govern anyone who insults or defames other people's religions and beliefs. This rule is the same as the law regarding blasphemy in Indonesia as stipulated in Article 156a of the Criminal Code. The difference is if this rule applies to all adherents of the religion or all citizens in Indonesia who commit blasphemy against other religions, both oral and written. Meanwhile, in Malaysia, the above regulations only apply to Muslims. Besides, in Malaysia, there is no specifically drafted law regulating blasphemy. In the Kanun Keseksaan itself, there are only rules in prohibitions against causing riots or disturbing other religions.

The sanctions gave only apply to Malaysian citizens who are Muslim. The penalty is a fine of not more than $5000 \mathrm{RM}$ and imprisonment of not more than 3 years by the Sharia Court. If non-Muslims such as Christians, Confucians, or Buddhist's insult Islam on the Internet or make deliberate words to hurt someone's religious feelings, they will be subject to sanctions as stipulated in the Deed of Communication and Multimedia and Kanun Keseksaan.

Also, some problems have not been regulated in the Law in Malaysia, namely political campaigns' problem to gain public sympathy. For example, looking down on other parties to draw sympathy utilizing hate-speech, hoaxes, hoax news, and slandering other parties does not 
exist. Apart from that regarding the threat of freedom of speech, the Kingdom does not yet know the extent to which it limits freedom of expression to regulate what is allowed and what is not. For example, in the chapter on religion, there are no limits on what needs to be discussed and what should not be so that this is the right time, and it is necessary to have rules to limit this behavior. With increasingly complex problems and supported by increasingly advanced technological developments, Malaysia has started to design regulations by separating errors related to religion to make specific rules. The rule will also be expanded by adding to the Cyber Crime case by including the existing rules in Jinayah regarding cybercrimes.

\subsection{Discussion}

\subsubsection{The polemic of blasphemy law in Indonesia}

According to YLBHI records, there were 38 reports of cases of religious blasphemy throughout 2020. Interestingly, 19 cases occurred during the pandemic. There are several cases of freedom of religion and belief against minorities. These cases are: (1) On March 16, 2020, a group of masses calling themselves the Alliance of Fort Aqidah (ABA) pressured the Bogor Regent to ban Ahmadiyah in the Regency; (2) On April 6, 2020, the Tasikmalaya Regency

Government through Bakorpakem attempted to seal the Al-Aqsa Mosque belonging to the Ahmadiyah congregation in Badakpaeh Village, Cipakat, Singaparna District; (3) In July 2020, there was a seal on the prospective family funeral or pasarean of the Sunda Wiwitan Karuhun Urang (AKUR) Adat at Curug Goong, Kuningan by Satpol PP; (4) Using COVID-19 as an excuse to increasingly hate, vilify, or carry out bad schemes against ethnic Chinese, such as unhygienic and disease carriers; (5) Some leaflets or flyers addressed to Shia groups. For example, they are spread on several social media memes and posters stating that Shia is more dangerous than COVID-19; (6) On August 8, 2020, a group of paramilitary troops broke up a prayer ceremony in Midodarenan, Solo, causing injuries to 3 people. The event is considered a Shia tradition [21].

Many cases of blasphemy stem from the belief that they do it as a policy. For example, what happened to FPI members who attacked mosques belonging to Ahmadiyah followers? They said: "We are not giving up, for the truth we are ready, ordinary imprisonment, being thrown away means sightseeing, and being killed then martyrdom." This is embedded in their belief in attacking different minorities. Forcing them to the right path to save them from hell. Make this a sacred mission at the expense of other religious beliefs to the point of losing the lives of others. Third, the euphoria of harmony. For example, the word harmony is more widely used so that minority groups follow what the majority group does to hear what the majority group decides [22].

For example, many cases that occurred in a group of Shia in Bogor were prohibited from commemorating the Ashura celebration to avoid chaos. Besides that, it also prohibits or limits the activities of minorities, so it is believed to protect the many victims. By expelling the Shia from Sampang, it can build a society of harmony. The logic of harmony is identical to the domination of certain groups to suppress other groups. Fourth, the conservative mental construct is to silence and approve of intolerant and discriminatory attitudes that occur in society and think that various groups of people who are attacked deserve to be treated like that because what the minority groups do causes unrest towards the majority group. Lastly, delimited pluralism, which is an understanding that gives rise to clarity in performing religious services. For example, stated in Law No. 1/ PNPS/ 1965 on three categories of religion [23]:

a. Groups of six religions "embraced by the population of Indonesia." 
b. Religious groups referred to in PNPS / 1965 as "allowed to exist," such as Baha'i, Sikhs, and Jews.

c. Adherents of the belief are quite numerous and scattered in various places in Indonesia. Indonesia is considered not to have a strong legal basis, which causes minority groups to have no clear status in contentious belonging. One of the crucial things in our regulation lies in the 1945 Constitution Article 28J paragraph (2), which reads, "In exercising his rights and freedoms, every person is obliged to submit to the restrictions set by law to guarantee recognition and respect for the rights of freedom of people. Other and to fulfill just demands under moral considerations, religious values, security and public order in a democratic society". This verse is used arbitrarily for certain interests by the government in limiting religious freedom to certain groups [24].

Based on the results of a national seminar conference put forward by the Indonesian Legal Aid Foundation (YLBHI), it was stated that since January-May 2020, in Indonesia, there were 38 cases related to blasphemy, and this has led to a new trend, namely many cases have occurred in vulnerable areas, namely South Sulawesi, East Java, and North Maluku [25].

As is well known, in the legal text in Indonesia, there is no visible what exactly is meant by blasphemy. The 3 articles used are the Criminal Code, the ITE Law, the Mass Organization Law (in the word blasphemy, it is different from other blasphemy rules). Based on the analysis, the ITE Law makes the age of the charged suspects younger (mostly under 15 years). For example, this occurred in underage children who were suspected of playing the song Aisyah, playing TikTok, and so on. The police's keyword to bring cases to the realm of law is viral, indicated by causing public unrest, thus threatening public order. In fact, the reasons for disturbing order are not stated in the Article in the existing regulations.

Besides that, in Indonesia, there are many cases where there is no proof. As if forced to be convicted, such as the absence of evidence becomes evidence used in the toa mosque case in the "Meliana" case. There is also evidence that is not valid or evidence that was only made after the incident occurred, such as in the Fatwa case of the Tajul Mulk case in Sampang (only available after being reported by the public).

In Indonesia, blasphemy is considered the same as religious blasphemy (although they are two different things and violate criminal theory). In fact, in some cases, the word "blasphemy" is more popular than blasphemy. Also, there has been an expansion in the use of articles for acts deemed blasphemy due to the absence of a clear definition, causing law enforcers to be influenced by mass or public pressure for cases described as "viral." Public order-disorder is still a reason to arrest or process the case. However, there seems to be progress towards better law enforcement, both police and judges, although the numbers are minimal and more individual in nature. Finally, according to YLBHI, if the state intends to protect people, including religious communities, from acts of hostility, hatred based on ethnicity, religion, race, and other attributes, then the articles of hate crime, hate broadcasts, and discrimination are more effective [26].

Besides, Komnas HAM also stated that the problems of blasphemy offenses in Indonesia include: (1) The elements of the article tend to be ambiguous and have multiple interpretations (it can be imposed on anyone); (2) there is an element of discrimination, especially for minorities; (3) it has an impact on socio-politics (for example, during an election, it is certain that cases are more prone to arise). Komnas HAM stated that it is more concerned with Freedom of Belief and Religion and has made Standards for Norms and Regulations on Freedom of Religion and Belief, which are rules and measurements in assessing efforts to promote, fulfill, and protect the right to freedom of religion and belief in Indonesia which used in drafting and implementing rules. 
Also, Komnas HAM has provided recommendations to the DPR and the Government in the discussion of the Criminal Code Bill in September 2019: "... it is necessary to look again at the purpose of using the phrase expressing feelings and defamation as an alternative and equivalent of" hostility "needs to be reconsidered." In the Draft Criminal Code [27]:

a. Regulations regarding religion overlap with the ITE Law. Encourage the provisions of articles related to blasphemy to emphasize a clearer formula than blasphemy, namely the definition of the phrase hostility.

b. Emphasizing religious blasphemy, in this case, hostility, to be included in a material offense means that it must first be proven its real consequences to avoid criminalization and arbitrary interpretation of law enforcement officials.

Thus, Komnas HAM believes that the entire blasphemy regulation must be reviewed because it disturbs individual rights and has social impacts such as riots and division [28].

\subsubsection{Freedom of religion belief [29]}

Freedom of Religion Belief can be found in Article 18 of the Covenant on Civil and Political Rights. In fact, this right is the right of everyone "to freedom of thought (thought), conscience, and religion." This right consists of freedom to determine a religion or belief of his own choice and freedom to practice his religion and belief, either individually or collectively, either in public or closed in activities: worship, obedience, practice, and teaching. Article 18 paragraph (2) of the Covenant regulates the prohibition of coercion, namely "no one can be forced so that his freedom to adhere to or determine his religion or belief according to his choice" is disturbed. Meanwhile, the provisions of Article 18 paragraph (3) regulate permissible or legal restrictions. The requirements are:

a. Only for freedom to practice religion or belief;

b. Can only be limited by provisions under the law;

c. It is necessary to protect the safety, order, health, or morals of society or others' fundamental rights and freedoms.

The final provision in Article 18 of the Covenant on Civil and Political Rights is the relationship between parents and the State: "States Parties to the present Covenant undertake to respect the liberty of parents and, where recognized, legal guardians, to ensure religious and moral education for their children according to their own beliefs". This provision is similar to Article 14 paragraph (2) of the Convention on the Rights of the Child, namely "States parties must respect the rights and obligations of parents, and where applicable, legal guardians to instruct the child in exercising his rights in an appropriate manner. with the child's developing abilities ".

The provisions above do not necessarily cover the relationship between parents and children regarding Freedom of Religion or Belief. First, the principle of non-cooperation, as stated in article 18 paragraph (2) of the ICCPR, applies. Then Article 14 paragraph (1) of the Convention on the Rights of the Child applies, namely, "States parties must respect the right of the child to freedom of thought, conscience and religion providing that no one, including parents to children, violate this obligation." Also, there is Article 1 paragAccordingof the Convention on the Rights of the Child, which regulates "States Parties must take all appropriate steps to ensure that children are protected from all forms of discrimination or punishment based on the status, activities, opinions expressed or beliefs of the child's parents, the child's legal guardian or family member of the child ". Also, Article 14 paragraph (1) of the Convention on the Rights of the Child, namely, "States Parties must respect the right of the child to freedom of thought, conscience, and religion. In principle, as regulated in Article 3 paragraph (1) of the Convention 
on the Rights of the Child, "In all actions concerning children, carried out by state or private social welfare institutions, legal courts, administrative authorities or legislative bodies, the best interests of the child must be the main consideration."

\subsubsection{Slice of freedom of religion, beliefs with other rights [30]}

Slicing or intersectionality is a new approach used to see the relationship between a right and another. For example, in the mandatory regulation of religious clothing, apart from violating the right to $\mathrm{KBB}$, especially obedience, it can also be seen from the right to expression and women's rights.

An important provision in this section is hate broadcast as regulated in Article 20 (2) of the KIHSP. Hate broadcasts are "any action that promotes hatred based on nationality, race or religion which is an incitement to discrimination, hostility or violence." It is the obligation of the state party to prohibit it by law. Another slice is regarding minority groups as regulated in Article 27 KIHSP. It completely reads, "in countries that have minority groups based on ethnicity, religion or language, people belonging to that minority group must not be denied their right in society, together with other members of their group, to enjoy their own culture, to practice and practice their own religion, or use their own language."[31]

\subsubsection{Blasphemy vs. freedom of expression}

On the one hand, the implementation of the blasphemy law is to protect religions in Indonesia. However, on the other hand, Indonesia already has legal and human rights instruments that regulate and protect freedom of expression, conscience, religion, and worship according to its religion and belief. This fact gives birth to a certain complexity. On the one hand, freedom of expression and belief is protected by the constitution. On the other hand, these freedom practices often violate certain religious signs, so that they are called blasphemy. Article 28E and Article 29 of the 1945 Constitution guarantee every person or population's freedom or independence to embrace a religion and worship according to that religion. Article $28 \mathrm{E}$ paragraph (1) states, "Everyone is free to embrace a religion and worship according to his religion, ... etc.," This is also strengthened through article 29 paragraph (2) "The state guarantees the freedom of every citizen to embrace his religion and to worship according to religion. and that belief, ".

Various international instruments have also been ratified by the Indonesian government relating to freedom of expression and freedom of belief. Article 18 of the Covenant on Civil and Political Rights of the United Nations (International Covenant on Civil and Political Rights, ratified by Law 13 of 2005), paragraph 1 reads: "Everyone has the right to freedom of thought, belief, and religion. This right includes freedom to determine religion or belief of his own choice, and freedom, either individually or collectively with others, either in public or in private places, to practice his religion and belief in worship, obedience, practice, and teaching".

\subsection{Blasphemy law and human rights challenges in Indonesia}

Indonesia is the fourth most populous country in the world, which is also considered the country with the largest Muslim population globally, a country with thousands of languages, ethnicities, and cultures has complex and special conditions that make human rights discourse possible. Varies from the source. 
The Indonesian government enacted the Human Rights Law in 1999 and the Human Rights Court Law in 2000. This has also amended the Indonesian constitution and included ten articles/articles relating to human rights in 2000. Furthermore, in 2005, Indonesia finally ratified two international treaties considered the International Human Rights Law, namely the International Covenant on Civil and Political Rights and the International Covenant on Economic, Social and Cultural Rights of 1966.

Human rights articles enshrined in the amended Indonesian constitution and in Indonesian Law no. 39 are essentially the same as those enshrined in the Universal Declaration of Human Rights of 1948, the International Covenant on Civil and Political Rights 1966, and the International Covenant on Economic, Social and Cultural Rights 1966. However, things are very different when they come to implementation. These rights.

The Indonesian government and society sometimes have different ways of implementing human rights. The long term of colonialization and imperialism, more than forty years under dictatorship, poverty, and large numbers of jobs have made discourse - not to mention implementation - of human rights less attractive than other things that are done. Some people say that we accept human rights as long as they conform to our religious and social values. Others argue that human rights only come from western culture. Among human rights areas that have received many controversies are freedom of religion/conscience, freedom of marriage, sexual orientation/gender identity, and abortion.

Therefore, the Blasphemy Law in Indonesia has a legal basis and is also justified by the Indonesian socio-cultural-political atmosphere. Following are some of the arguments echoed by prominent Indonesian Muslim scholars (From Muhammadiyah, Nahdlatul Ulama, and the Indonesian Ulama Council) in response to the juridical review of the blasphemy law no. 1/1965 petitioned by NGOs and minority groups: The Blasphemy Law is seen as important for the community. Maintenance of social order and peace. It is necessary to prevent religious conflict and anarchy. The Blasphemy Law is an allowable and necessary limit on the right to freedom of religion in public order interests, as permitted by the constitution. Freedom of religion is not absolute freedom without limits. The conception of human rights in Islam compared to that of the "West" is different. Western concepts of human rights are often indefinite and narrowly focused on individual rights. This contrasts with human rights in Islam, and therefore in Muslimmajority Indonesia, he argues, places equal emphasis on individual responsibility in society.

Lessons learned from North Sulawesi include that blasphemy law is still needed to regulate religious harmony among people living in a multicultural society. However, an informal approach to resolving religious clashes through dialogue among informal religious leaders, as demonstrated by BKSUA and FKUB in North Sulawesi, is much more important for maintaining religious harmony.

From the perspective of the effectiveness of applying the articles of blasphemy, the above case is considered inappropriate if it is categorized as a case of actual religious deviation or blasphemy. This can be seen from the facts that occur in the local community when the chanting of the call to prayer echoes to the procedures for praying in Javanese or terms of the difference in the number of prayer congregations, so far there has never been a problem or debate regarding that issue. Regarding the blasphemy law itself, there is still a need for regulation regarding this matter. However, what needs to be underlined is how the legal provisions' direction operates in regulation because basically, the present rules aim to maintain public order in society. With the PNPS Law's existence, it needs to be narrowed even further so that people do not criticize each other's beliefs. The importance of this PNPS Law is enforced to maintain harmony and public order in society because ideologically and juridically, it does not contradict Pancasila's values. 
Various polemics arise in people's thinking when discussing the blasphemy law's effectiveness in creating public order. This can be seen from the legal structure, law enforcement agencies, legal culture, and other legal factors. So far, the PNPS Law's effectiveness has been quite effective, but certain restrictions are needed. If we look at Article 156 of the Criminal Code or usually in the prosecutor's indictment, it is alternated with Article 33 of the ITE Law regarding unpleasant acts. Of course, the Judge has determined Article 156.

A of the Criminal Code because it explicitly regulates religious blasphemy. For example, the blasphemy decision in the Klaten area stated that the prosecutor charged Article 45 paragraph (2) of the ITE Law; however, the judge ruled Article 156(a) of the Criminal Code. If viewed juridically, the existence of this PNPS Law should be lex specialis compared to the Criminal Code. However, usually, judges actually have different considerations, namely because Article 156 of the Criminal Code is related to religious blasphemy, so that it ignores the sound of other articles. At the same time, in the regulation of the ITE Law, it is more related to SARA, which is broader in definition than Article 156(a)of the Criminal Code, so generally, the judges always stipulate to Article 156(a) of the Criminal Code regarding blasphemy of religion because it is easier to prove the elements of the article in court.

Not only that, the presence of Article 156 of the Criminal Code is still considered unfair and does not rule out injuring the community. In general, all judges are the same in defining public order. In the case of translation of public order, judges usually draw from the same definitional term in the absence of consensus. According to the doctrine, the definition of "public place" is a place that is accessible to the public. Includes access to social media, which is included in the category of public places and can be subject to the ITE Law. Still, in reality, only Article 156 of the Criminal Code is imposed.

In essence, law enforcers in solving the problem of blasphemy within the judiciary are using articles that are easy to apply, such as Article 156 of the Criminal Code and from the point of view of the ease of proving the elements. In general, the evidence brought by the prosecutor is in the form of an MUI fatwa (proof of letter). In this case, some things should be considered by judges in determining a case, including blasphemy, namely, in addition to seeing the facts of the MUI Fatwa (deviant or not), the judge will also see in terms of the impact of his actions disturbing public order or not and consider the element of "intentionally" in the context of deliberate intent or willens en wettens, namely the will and knowledge of the doer. Then, consider also in terms of whether the perpetrator gave an apology or not, considering from the history of the perpetrator how long it had been for the perpetrator to commit an act that led to blasphemy and the intensity of the time for how long it took to commit an act that blasphemed religion. Therefore, the government's role is very much needed to guide people with various religions and beliefs to maintain harmony and create order among religious communities.

\section{Conclusion}

Many people still consider the enforcement of the blasphemy law in Indonesia to be incompatible with human rights. However, the enforcement of this blasphemy law has a legal basis and justification per Indonesia's social, cultural, and political context.

Secondary data research and field research conducted in several regions of Indonesia, including East Java, West Sumatra, North Sulawesi, and Bali, as well as a comparative study with three countries in Southeast Asia, respectively the Philippines, Malaysia, and Thailand, show the results that legal regulations related to blasphemy religions in Indonesia (especially in 
the Criminal Code) have not accommodated all cases in fact. Meanwhile, in the four foreign countries mentioned above, regulations on blasphemy laws still exist, but their implementation varies and does not reflect legal certainty. In the Indonesian context, certainty is needed regarding the regulation of the blasphemy law and the explanation of the related articles to achieve public order and legal certainty in Indonesia's pluralistic society.

In addition, rights regarding minorities become a problem because in every religious conflict, the approach is always harmonized where minorities are often sacrificed, and their rights to have a religion, belief, and worship are not fulfilled. This tendency must be ended where the belief is an individual right; it does not recognize the majority and the minority. Law enforcers must receive reinforcement, lightening up, and encouragement to enforce the law. They do not get pressure from the minority and the majority. This is the main reason for the fulfillment of political rights and ECOSOC. If we make efforts to evaluate it, it is hoped that there will be outputs or outputs to be processed in policy making so that there are no restrictions.

\section{Acknowledgment}

This paper is written as an output of research conducted as part of a research grant from the Ministry of Research and the Higher Education Republic of Indonesia under the PDUPT scheme year $2018-2020$.

\section{References}

[1] Article in Tempo Magazine (https://en.tempo.co/read/news/2017/05/10/055874088/MajorBlasphemyCases-in-Indonesia) mentions the largest cases of religious blasphemy in Indonesia, namely as follows: Arswendo Atmowiloto , Chief Editor of the Tabloid "Monitor", which put the Prophet Muhammad in 11th position and Suharto in 1st place in a headline entitled "50 Figures that Readers Admire" who are deemed to have insulted Islam, was sentenced to 5 years in prison by the Central Jakarta District Court ( April 1991). Lia Eden, leader of a sect called the "Holy See of the Kingdom of God" (God's Kingdom of Eden). Indictment: 2 years 6 months in prison. Verdict: 2 years 6 months imprisonment by the Central Jakarta District Court (June 2009). Tajul Mukul alias Haji Ali Murtadho, Shia leader in Sampang, East Java. Indictment: 4 years in prison. Verdict: 2 years imprisonment at the Sampang District Court (July 2012). Antonius Richmond Bawengan, distributor of books and leaflets that blaspheme religion. Indictment: 5 years in prison. Verdict: 5 years imprisonment by the Temanggung District Court (February 2011). Rusgiani, a housewife, insulted the offerings in Hindu religious ceremonies with dirty words. Indictment: 2 years in prison. Verdict: 14 months imprisonment by the Denpasar District Court (October 2013). 6 (six) Administrators of the Fajar Nusantara Movement (Gafatar). Indictment: 4 years. Verdict: 3-4 years imprisonment by Banda Aceh District Court (June 2015). Abdussalam alias Ahmad Musadeq, Gafatar Leader, indictment: 12 years imprisonment. Verdict: 5 years imprisonment by the East Jakarta District Court (March 2017).

[2] Look at Amnesty International, Prosecuting Beliefs: Indonesia's Blasphemy Laws, Amnesty International November 2014 Index : ASA 21/018/ 2014.

[3] Ibid.

[4] Ibid. Look at Siti Aminah, et.al, Ketidakadilan Dalam Beriman Hasil Monitoring Kasus-Kasus Penodaan Agama Dan Ujaran Kebencian Atas Dasar Agama Di Indonesia, The Indonesian Legal Resources Center, Jakarta, 2012.

[5] Siti Aminah, et.al., Ibid. 
[6] Look at https://www.republika.co.id/berita/nasional/daerah/17/12/06/p0jcmk409-hina-islamdonald-bali-divonis-2-tahun-10-bulan-penjara

[7] Data optained from field research in Bali in November 2018.

[8] The full text of the SKB Three Ministers can be downloaded here : https://jatim.kemenag.go.id/file/file/pdf/edzh1450431972.pdf.

[9] Interview with representatives of the Ahmadiyah congregation in Surabaya on September 2019.

[10] Look at https://regional.kompas.com/read/2012/09/08/10225657/menag.inti.masalah.sampang.ada.di.roistajul.muluk.

[11] Field interviews in Surabaya and Madura, September 2018.

[12] Look at Library of Congress, "Blasphemy and Related Laws,: accessible at http://www.loc.gov/law/help/blasphemy/blasphemy.pdf.

[13] Ibid

[14] Andi Hamzah, Delik-Delik Tertentu (Speciale Delicten) di dalam KUHP, (Jakarta: Sinar Grafika, 2015), pp. 247-249.

[15] Muhammad Dahri, "Tindak Pidana Penodaan Agama Di Indonesia: Tinjauan Pengaturan PerundangUndangan dan Konsep Hukum Islam”, (AT-TAFAHUM: Journal of Islamic Law, Vol.1 No.2, 2017), pp. 59.

[16] Ibid., pp. 59-60.

[17] Ibid.

[18] Based on field research in Bangkok and Pattani, Thailand on November 2019.

[19] Based on field research in conducted by the Research Team on November 2020 to Manila, Philippines.

[20] Based on field research in Kuala Lumpur Malaysia on November 2019.

[21] Based on the Online Conference Presentation Slide by Ahmad Najib Burhani (LIPI) with the titled "Challenges of Religious Minorities in Indonesia", accessed on 18 August 2020.

[22] Ibid.

[23] Ibid.

[24] Ibid.

[25] Based on Online Conference Presentation Slides by YLBHI with the theme "Blasphemy Law: Protection or Criminalization?", accessed on 27 August 2020.

[26] Ibid.

[27] Based on Online Conference Presentation by Komnas HAM with the theme "Blasphemy Law: Protection or Criminalization?", accessed on 27 August 2020.

[28] Ibid.

[29] Based on Online Short Course by Paritas Institute with the theme "Freedom of Religion and Belief", accessed on 25 August 2020.

[30] Ibid.

[31] Amnesty International, Mengadili Keyakinan Undang-Undang Penodaan Agama, Jakarta, November 2014. 